\title{
INVASION OF PRIVACY
}

JEREMY S. WILLIAMS*

\begin{abstract}
The lack of a coherent theory of privacy is at the root of the inadequacy of present-day legal measures to afford protection of the indivisible "social space" surrounding each individual. Professor Williams, in recognizing some of the difficulties involved in defining the sphere of an individual's interest in privacy, emphasizes the threat posed by the gathering and dissemination of information about an individual without his knowledge or authority. This threat, says Professor Williams, cannot be neutralized by the individual himself; there must be judicial or legislative intervention on his behalf. Common law torts, while they do give some protection, are not sufficient: the remedies are both slow and costly, and, of course, are not available to one who is not aware that his privacy has been invaded. Statutory enactments such as those in Manitoba and British Columbia give only a broad and general protection against invasions of privacy; and other legal protection (which only incidentally affects privacy-intrusive conduct) is both sporadic and limited. A rational theory of privacy, the author concludes, is essential to effective protection against invasions of privacy.
\end{abstract}

\section{INTRODUCTION}

Invasion of privacy may take many forms. Although invasions of privacy are usually presumed by tort lawyers to fall within the area left uncovered by defamation, negligence and the other tort remedies, in modern times such a restricted view will not yield a sufficiently coherent theory of privacy. Expanded horizons of the concept of privacy produce the notion that there is one indivisible "social space" surrounding an individual which may be invaded or intruded upon in a variety of different ways. These intrusions into the privacy of a person are the aggravations and frustrations to which an individual is unreasonably subjected. The extent of this sphere of privacy may be determined by examination of precisely which intrusions are thought by most people to be unreasonable. ${ }^{1}$ In this context Freund states: ${ }^{2}$

Offensive shadowing in a public place also came to be treated as a wrong, "like" eavesdropping, though without the element of trespass. These can be characterized as instances of distressing intrusion into the private domain of living or into the sphere of a person's autonomous movement.

The sphere of an individual's interest in privacy ought to be sufficiently wide as not to defeat normal expectations. Despite the fact that there may be general agreement as to the ambit of such an interest there has been great difficulty in defining it. Definitions and descriptions of privacy interests have been notoriously unsuccessful when made at a high level of abstraction. Because of this it is difficult to draw up concrete proposals or guidelines on the basis of the theoretical and philosophical analyses of the subject. However, when such descriptions have been concrete and specific, the forms of intrusion of privacy

\footnotetext{
- LL.M. (Sheffield), B.C.L. (Oxon.), of Lincoln's Inn, Barrister-at-Law. Professor of Law, Indiana University.

1 It is recognized that other methods of determining the appropriate sphere of privacy to be legally protected exist. The test of the ordinary reasonable man seems to have been tacitly accepted by judges in these cases to weigh the reasonableness and justification for conduct against the social value of the intrusion. See Davis v. McArthur (1971) 17 D.L.R. (3d) 760; and Melvin v. Reid (1931) 297 P. 91.

2 See Pennock and Chapman, Privacy, chapter 10, (1971).
} 
described have been regarded as particular types of offensive conduct rather than as part of the larger unity, the interest in privacy. In this way, utility may be sacrificed by a failure to be specific, or cohesion by being too specific. However, both the conceptual and the limited and practical approaches have great value.

Interests in privacy, like most other legally recognized interests, must be balanced against countervailing interests on the part of society as a whole as well as against the interests of other individuals. For example, the individual may assert that he has a right to some control or review of reports compiled upon him but this assertion must be balanced against the claims of those who amass, store and retrieve information for a living, as well as against the "right to know" of the general public and freedom of speech. ${ }^{3}$ One of the problems which is here confronted is that some businesses amass information on individuals, maintaining a file on each individual and distributing a copy of the file on request and payment. ${ }^{4}$ Others undertake investigations on a named individual for a particular client. Private investigators and commercial credit reporting agencies both indulge in these activities. ${ }^{5}$ The threat posed by the information gatherers, whether collection is for the purpose of maintaining file reports or to satisfy a particular client's desire to have an investigative report on an individual, is one of the most serious. Information may also be gathered by government agencies, and this is usually done under some statutory threat of penalty for non-compliance. Examples are information collected on tax or census forms. The principal reason why disquiet has been caused by the knowledge that a large amount of information has been gathered on individuals in recent years is that once information has been collected it is controlled by the gatherer of it. Because of this, the subject of the information has no control over it and there is no certainty that anyone who is interested in either its accuracy or its restricted circulation has any control. ${ }^{6} \mathrm{~A}$ secondary reason for concern, is that associated with the activities of information gatherers may be some laxity in the gathering, storage and dissemination of the information. Improper, unreliable and inaccurate means of obtaining information may be used, safe storage may not be maintained, and the information may be supplied to anyone who requests it and pays the requisite fee.

This is to a large extent the reason for the attention paid in modern times to the questions concerning invasions of privacy. There are, however, instances of privacy-intrusive conduct unconnected with any gathering or handling of information. These concern the questions of intrusion and undue publicity with which tort lawyers have been concerned for decades. ${ }^{7}$ This has been the case because the law of

3 Freedom of speech is specifically protected by s. 1(d) of the Canadian Bill of Rights, R.S.C. 1970, App. III, which legislation is paramount to other federal legislation: $R$. v. Drybones (1970) 9 D.L.R. (3d) 473. However, a great deal depends on the judicial reconciliation of such a broad and general right with the presumably more precise directives of a particular statute.

- See Sharp, Credit Reporting and Privacy (1970); Miller, The Assault on Privacy (1971); and Westin, Privacy and Freedom (1967).

3 See, for example, the activities alleged to have been undertaken in Davis v. McArthur (1971) 17 D.L.R. (3d) 760; Cossette v. Dun (1890) 18 S.C.R. 222; Macintosh v. Dun [1908] A.C. 390; and Sawatzky v. Credit Bureau of Edmonton Ltd. (unreported) May 19, 1970.

- Some, apparently like Toffler, Future Shock (1971), would assert that the lack of control is the most important problem.

7 There have been debates on the extent to which the law of torts and other branches of the law should protect privacy, at least since the article written by Warren and Brandeis, The Right to Privacy, (1890) 4 Harv. L. Rev. 193. This debate has continued to the present. See Taylor. Privacy and the Public, (1971) 34 Mod. 
torts has not given redress for these two types of interference with an individual's sphere of privacy. This failure of the law of torts has been given added significance by the development of equipment enabling very close (and sometimes unexpectedly close) contact between individuals. Just as the information-gathering process has been revolutionized by the computer, so intrusions on the solitude of another have been greatly facilitated by the parabolic microphone, other small microphones and tiny cameras. Whereas the possibility of intrusion is increased by this sort of equipment, the possibility of undue or improper publicity has always existed. However, it is more likely to occur today because of the greater and swifter exchange of information that now takes place.

Nevertheless, increases in the spread of information and the development of new technical equipment are generally beneficial. However, these benefits must be balanced against the benefits to be derived from the individual's retention of some sphere within which he has freedom and control. The reason why we should be concerned is that it may be impossible for a natural balance to be struck. It may not be feasible for individuals to band together to retrieve this control without some judicial or legislative intervention on their behalf. ${ }^{8}$

\section{TYPES OF INTRUSION}

Given such a broad framework within which various invasions may occur, we must expect a corresponding increase in discernible types of intrusion. When a particular type of intrusion is discerned the question remains whether it ought to be discouraged and what the most effective means of achieving this end is. The broad classifications of intrusion consist of:

\section{Publicity}

The wrongs apprehended here include criminal, tortious, improper or undue publicity. Inappropriate publicity may undoubtedly be harmful not only to the sensibilities of an individual but it may have tangible deleterious effects on him. ${ }^{9}$ Excessive publicity to be actionable need not be restricted to a newspaper report but may extend to any publication. ${ }^{10}$ Privacy-intrusive conduct within this rubric might include:

(1) Improper publicity which creates a false impression in the eye of the public. ${ }^{11}$ If this publicity is so damaging as to lower the reputation or esteem of the plaintiff in the eyes of right-thinking members of the

\footnotetext{
L. Rev. 288; Miller, Personal Privacy in the Artomated Society, (1969) 67 Mich. L. Rev. 1089; and Nottingham, Right of Privacy and Emotional Distress in Colorado, (1971) 43 U. Col. L. Rev. 147.

s It should be realized that a laissez-faire attitude may no longer be sufficient to assist people to protect their own privacy. Only very wealthy individuals now have the means and ability to control completely their own environment.

- Particular types of publicity may cause a person to be inundated by salesmen, unwanted merchandise, soliciting letters or telephone calls. See Robbins v. CBC (1957) 12 D.L.R. (2d) 35. It was suggested in one case in California that telephone companies ought to be required to print an asterisk in the telephone directory beside the name of those who do not wish to receive telephone solicitations: McDaniel v. Pacific Tel. and Tel. Co. (1965) 60 P.U.R. (3d) 47 (California Public Utilities Commission). A suggestion like this, together with appropriate parallel restrictions on other confrontations by salesmen, may be employed to minimize the harmful results of excessive publicity.

${ }^{10}$ In the sense used in the tort of defamation. Prohibition of publication is a means of greater harm flowing from a previous wrong and, as such, is an additional and secondary sanction designed to prevent the commission of the criginal wrong.

"I This is Prosser's fourth category of the tort invasion of privacy; Prosser, Torts 812 (4th ed. 1971).
} 
community, it will be actionable in defamation. ${ }^{12}$ However, that tort does not cover all cases of misleading and improper publicity. ${ }^{13}$

(2) Appropriation, for the defendant's benefit or advantage, of the plaintiff's name or likeness. ${ }^{14}$ In these situations redress has usually been available in Canada and England for either breach of copyright, ${ }^{15}$ defamation ${ }^{16}$ or the tort of passing-off. ${ }^{17}$ In both breach of copyright and the tort of passing-off serious questions may arise as to who has copyright or ownership. In these torts strict legal proprietary rights matter more than what people reasonably think. ${ }^{18}$ When there is a commercial exploitation of name or photographic or artistic likeness of the plaintiff it is fairly widely conceded that there ought to be some remedy in tort. If invasion of privacy will not lie then the tort of defamation ought to provide redress. ${ }^{19}$ However, reproduction or limitation of other distinctive attributes of the plaintiff might also reasonably lead to an award of damages. ${ }^{20}$

(3) Unauthorized revelation of private information. Such a disclosure may be permitted either by the individual who is most nearly concerned, by the person within whose disposition it is or by statute, ${ }^{21}$ presumably enacted for the general good of the public. ${ }^{22}$ In any of these cases publication is not usually regarded as objectionable. Nor is publication offensive when it concerns a public official or public figure. ${ }^{23}$

12 Before recovery may be had in defamation the judge must be satisfied that the plaintiff s reputation is actually and reasonably affected.

13 This may be a good argument for the introduction and recognition of a common law tort of invasion of privacy. However, there has been some judicial reluctance to do so, partly because judges in England and Canada are very much less accustomed to judicial legislation than are their counterparts in the U.S.A.

14 The only jurisdictions in the U.S.A. that might today follow Roberson v. Rochester Folding Box Co. (1902) 171 N.Y. 538, 64 N.E. 442 and deny recovery to a girl whose photograph was unauthorizedly reproduced on a bag of flour are Nebraska, Rhode Island, Texas and Wisconsin. English and French courts have always been ready to award damages in such cases: Pollard v. Photographic Co. (1888) 40 Ch.D. 354; Correlli v. Wall (1906) 22 T.L.R. 532; Williams v. Settle [1960] 2 All E.R. 806; and Wagner, The Right to One's Own Likeness in French Law. (1970) 46 Ind. L.J. 1.

is Williams v. Settle [1960] 2 All E.R. 806.

16 Tolley v. Fry [1931] A.C. 333.

17 Krouse v. Chrysler Canada Ltd. (1972) 2 O.R. 133.

18 It was held in Sim v. Heinz [1959] 1 All E.R. 547 that no damage could necessarily be shown to ensue from the imitation of a voice. In that case, no argument was offered on the question of the proprietary interest in a voice. Scientific advances may well make such a question moot when positive identification of voices by "voiceprint" may be regularly undertaken.

19 See Tolley v. Fry [1931] A.C. 333. The tort of defamation will be applicable where the requisite injury to reputation is shown.

${ }^{20}$ But see Sim v. Heinz [1959] 1 All E.R. 547. If an attribute is sufficiently distinctive then the plaintiff ought, perhaps, to have a proprietary interest recognized in it.

21 Clearly the person who is primarily the subject of the information may not be the person who has possession of it. The information may concern two or more persons equally. Rights between the two or more persons who may be involved in such situations may be regulated by the law of copyright or patents, that of contract, or that of breach of confidence. See Argyll v. Argyll [1967] Ch. 302; Yovalt v. Winyard (1820) 1 Jac. \& W. 394, 37 E.R. 425; Saltmann Engineering Co. v. Campbell Engineering Co. [1963] 3 All E.R. 413 (which was followed in Peter Pan etc. Corp v. Corsets etc. [1963] 3 All E.R. 402); Prince Albert v. Strange (1848) 1 Mac. \& G. 25, 41 E.R. 1171; Pope v. Curl (1741) 2 Atk. 342, 26 E.R. 608; and Lord Byron v. Johnston (1816) 2 Mer. 29, 35 E.R. 851. The result of all these decisions is that ordinary and reasonably held expectations will not be defeated.

22 Some statutes specify what matters are of public record. Land titles records and records of writs or statements of claim filed with the court may be matters of public record.

${ }^{33}$ Acts which are done, said or performed in public the courts have found to have sufficient public contact. English coure have recognized that there is a right of comment and of reply coextensive with the original comment made: Adam v. Ward [1917] A.C. 309. However, U.S. courts have gone farther and have allowed comments on public figures and public officials so long as they are not made with malice. This defence exists in both the tort of defamation and that of invasion of privacy and is founded on the First Amendment (to the U.S. Constitution) in which the right of freedom of speech is guaranteed in precisely the same terms as it is in the Canadian Bill of Rights, R.S.C. 1970, App. III, s. 1(d). The U.S. decisions supporting this proposition include: New York Times v. Sullivan (1969) 376 U.S. 254; Spahn v. Messner (1965) 260 N.Y.S. (2d) 451; Coleman v. Mackennan (1908) 98 Pac. 281; and Curtis Publishing Co. v. Butts (1966) 388 U.S. 130. The defence may even extend, as it was in Time Inc. v. Hill 385 U.S. 374 (1966) la case argued 
(4) Information required to be given by law and subsequently published in another connection may be objectionable. Furthermore, information obtained by coercion or trick ought not to be published at all. Most Canadians would have some moral reservations about the publication of information obtained by these means. Any prohibition of publication is designed to prevent some improper practice occurring at an earlier stage in the handling of the information. ${ }^{24}$

\section{Intrusion on Solitude}

This may be a trespassory or non-trespassory intrusion into an individual's usual retreat or into his private affairs. ${ }^{25}$ Such intrusions may be divided into two types:

(1) Deliberate or apparently deliberate intrusions. This refers to such acts as eavesdropping or spying upon a person in his home or office thereby deflecting reasonable expectations that transactions conducted in such places should be private. Who would expect a microphone to be concealed in the headrest of an airliner?26

(2) Surveillance or compilation of dossiers that is unreasonable in point of time or place. Most individuals feel that unreasonable surveillance or documentation should not be countenanced. ${ }^{27}$

\section{Control of Information Handling}

This affects all stages of the handling of information, whether collection, storage, exchange or dissemination of it. Some activities definitely prejudice the subject of them but others merely place the subject in some jeopardy. This amounts to a distinction between actual and inchoate invasions of privacy. ${ }^{28}$ Individuals feel threatened when they realize how much information is amassed about them by the various commercial and government agencies. They appear to feel particularly perturbed by the following possibilities:

(1) The collection, retention and dispensation of false information, improper impressions or misleading conclusions. Individuals are disturbed not only by the fact that mistakes are made but by the mere possibility that they may be prejudiced by mistakes.

(2) Collection of information may take place from sources that are dubious. Solicitation of indirect and second-hand information occurs regularly. The problem of such derivative information is that there is an increased danger of erroneous and misleading information being stored or dispensed.

(3) Control of information collected, retained or dispensed by the subject

by one R. M. Nixon] to the situation where the press has thrust the plaintiff into the "limelight" and has then commented upon him. These comments are then protected by the defence of "comment upon a public figure" unless they can be shown to be made with malice.

24 There are a substantial number of Canadian statutes providing penalties for improper disclosure of informa. tion gained under the statute.

25 Thus the invasion may be tangible or intangible. Insofar as it is intangible it may overlap with 1(c) above: unauthorized disclosure of privute information.

26 This example and others like it are set out in Pennock \& Chapman, Privacy (1971). This is a type of privacyintrusive conduct that is not adequately precluded by the law of torts. Without the tort of invasion of privacy only the torts of trespass quare clausum fregit and nuisance will be relevant.

27 Any legal protection that exists does so by virtue of the tort of negligence.

28 There is a distinction between recording inaccurate information on the files of individuals and the mere using of sources of information that may be inaccurate, misleading or prejudiced. People feel threatened by the simple collection of information. If they knew that the possibility of error was high they might feel correspondingly more threatened. 
of it appears to be completely disregarded. The present state of the common law recognizes proprietary interests, i.e., those of the collector of the information, but not those of the subject of the file. ${ }^{29}$

\section{TORT PROTECTION}

There is currently some general protection against privacy-intrusive conduct in the torts of defamation, negligent misrepresentation, passingoff, deceit and invasion of privacy (where it exists). ${ }^{30}$ Clearly, each of these torts is limited in terms of the protection it affords. It is also clear that there are some torts which have very little to do with privacy but which may assume a privacy aspect when the facts of the case are of a privacy-intrusive nature. An example of such a tort is trespass, whether to the person, chattels or land. The relationship of these torts to privacy is purely coincidental.

Defamation is the publication of false statements of fact or unfair comment which causes the subject of it to suffer hatred, ridicule or contempt or to have his reputation diminished in the eyes of rightthinking members of society. ${ }^{31}$ While this is a useful and necessary tort it is subject to two major disadvantages in connection with suppression of invasion of privacy. The first is that the defamatory words to be actionable must be untrue or unfair comment. ${ }^{32}$ This clearly limits the utility of the tort of defamation for it is unable to support an action against the maker of a true but harmful statement. Such a true statement might be the public revelation that a now quiet and unassuming housewife had been a prostitute and the defendant in a notorious murder trial. ${ }^{33}$ Similarly, a public announcement might be made that a person owes money and will not pay it. ${ }^{34}$ It is not suggested here that such situations ought to be cognizable by the law of defamation: it is merely intended to demonstrate that such circumstances go unredressed by it. On the other hand, there are several situations which have privacyintrusive aspects which are remedied by the law of defamation. Where false testimonials were attributed to the plaintiff he could recover in defamation. ${ }^{35}$ Pictorial representations of the plaintiff might also be actionable in defamation where they conveyed a false impression. ${ }^{36}$ Nevertheless, truth is an absolute defence. ${ }^{37}$ It is because of this that the tort does not assist in the marking out of a portion of the lives of individuals which ought to be inviolate and free from comment.

The second major disadvantage to the tort of defamation in terms of the protection of individual privacy consists of the existence of the

${ }^{29}$ He may bring an action for defamation if (1) he finds out the existence of the erroneous information, and (2) the information is actually untrue and prejudices him. See Macintosh v. Dun [1908] A.C. 390 and the examples in the Appendices to Sharp, supra, n. 4.

so Some think the tort of nuisance ought to be included in this list. See Lord Mancroft's comments in H.L. Deb., March 13, $1961 \mathrm{col}$. 617. This writer is of the opinion that the tort of nuisance is of marginal value in the protection of privacy.

II See Youssoupoff v. M.G.M. Ltd. (1934) 50 T.L.R. 581; and Byrne v. Deane [1937] 2 All E.R. 204.

32 They must be untrue with respect to a small enough group (including the plaintifn that he or she can be identified: Albrecht v. Burkholder (1889) 18 O.R. 287; Browne y. Thomson [1912] Sess. Cas. 359; and Ortenberg v. Plamondon (1913) 24 Que. K.B. 69, 14 D.L.R. 549.

33 Melvin v. Reid (1931) 297 P. 91.

34 Brents v. Morgan (1927) 299 S.W. 867.

3s Mazatti v. Acme Products Ltd. [1930] 4 D.L.R. 601; and Tolley v. Fry [1931] A.C. 333. See also Lord Byron v. Johnston (1816) 2 Mer. 29, 35 E.R. 851.

as Tolley v. Fry [1931] A.C. 333.

37 See Ray, Truth: A Defense to Libel, (1931) 16 Minn. L. Rev. 43. See also Kemslev v. Foot [1952] A.C. 345. 
defences of qualified and absolute privilege. The defence of absolute privilege is a subordination of the reputation of individuals to the necessary functioning of the legislative, executive and judicial branches of government. It is, quantitatively, not a major problem in terms of protection of privacy. However, anyone may be the subject of any such otherwise defamatory comment. The defence of qualified privilege is quantitatively more important. It is an available defence where the publisher and the recipient have a mutual interest in the making of the statement. Given the great increase in the communication of reports about other people which has taken place in recent years, this defence has become much more important. The exact scope of this defence is set out below. Communications regularly take place between commercial reporting agencies and private individuals about applicants for credit, for employment and for life insurance. Communications also occur between government agencies and individuals with respect to the same applicants. Many voluntary statements may also be made about third parties. In view of the large number of enquiries to which responses are made by such commercial and governmental agencies, these agencies have established fairly large records departments. ${ }^{38}$ Facilitation of the storage, retrieval and dissemination of such records will undoubtedly follow the computerization of them. ${ }^{39}$ Thus, the conclusion is that there are many situations in which there is a mutual interest between communicator and recipient in the subject of a report and there are likely to be many more as the availability of reports increases. The availability of these techniques may stimulate a great increase in the keeping of records for purely internal purposes too, and these will be situations in which the defence of qualified privilege will be available.

In England and Canada the same rules prevail as to the scope of the defence of qualified privilege. As observed it is a defence which is available where the publisher and the recipient of the statement have a mutual interest in the passage of the statement but the defence is not available where that mutual interest is a purely or primarily commercial one. ${ }^{40}$ The defence will prevail where the relationship is that of a volunteer of information to a recipient having a coextensive interest, ${ }^{41}$ or where the publication is internal to an organization or business and is necessary for conducting its affairs, ${ }^{42}$ or when the publication is made within a trade protection association or other similar body. ${ }^{43}$ By not allowing the defence to encompass commercial mutual interests the scope of the defence is reduced, which places the person

3s The chief commercial reporters are the credit reporting agencies, banks, associations of employers and associations of landlords. Among government agencies who make reports are the motor vehicles branches: other agencies simply allow access to public records concerning details of land transactions, registered personal property security interests, records of actions brought and bankruptcies. Other bodies, such as life insurance companies, employers and creditors, act as secondary sources and supply information to the commercial credit reporting agency.

39 The spread of computers in the commercial field is outlined by Sharp, supra, n. 4 at 18 et seq.

so See Macintosh v. Dun (1908] A.C. 390; Sawatzky v. Credit Bureau of Edmonton Ltd. (unreported) May 19, 1970; Cossette v. Dun (1890) 18 S.C.R. 222; and Lemay v. Chamberlain (1886) 10 O.R. 638. The rule is otherwise in all jurisdictions in the U.S.A. except Georgia and Idaho. See Wetherby v. Retail Credit Co. (1964) 201 A. (2d) 344; Indianapolis Horse Patrol Inc. v. Ward (1966) 217 N.E. (2d) 626; Johnson v. Bradstreet (1886) 77 Ga. 172; and Pacific Packing Co. v. Bradstreet (1914) 139 P. 1007. In the majority of states the defence is much broader than in Canada. This is in effect a shield around commercial agencies and its existence probably reflects a cultural difference as to the operation of commercial agencies.

1 Hunt v. Great Northern Ry. Co. [1891] 2 Q.B. 189.

42 Harper v. Hamilton Retail Grocers Association (1900) 32 O.R. 295.

4 London Association for the Protection of Trade v. Greenlands Ltd. [1916] 2 A.C. 390. 
about whom the report is made in a somewhat stronger position. Nevertheless, if the statement made is subject to a qualified privilege (it may, for example, be voluntarily made), the subject will have to prove malice on the part of the maker or excess of privilege before he may recover in defamation. ${ }^{44}$ Either of these claims, when substantiated, destroys the defence of qualified privilege where it does exist.

Thus the tort of defamation is useful in that it protects privacy interests to some extent; however, it is limited in that true statements are not within its purview and the defence of qualified privilege may be available in some circumstances. However, there is one purely practical limitation which is more important: the inability of the subject of a report to find out what is being said about him. This is emphasized by the fact that commercial credit agencies who might be liable in defamation contractually bind the recipients of their reports to secrecy. ${ }^{45}$

The tort of negligent misrepresentation may be available for the redress of some privacy-intrusive statements. The restrictions on the utility of this tort revolve around the facts that the statement must be false and must cause harm to the party who reasonably relies on the statement to his detriment. ${ }^{46}$ The tort of deceit is subject to the same deficiency in terms of the protection of privacy interests. The only major difference between it and negligent misrepresentation is the fact that the misstatement is made intentionally, wilfully or recklessly. ${ }^{47}$ The only impact which these torts may have on privacy interests depends on the coincidental factor of whether the statement made is about a private matter or the damage caused is thought to be of a very personal nature. One type of damage which is often thought to be of such a personal nature is nervous shock ${ }^{48}$ which is obviously one of the most private types of injury. Nevertheless, the circumstances under which the tortious conduct took place may not appear to have any privacyintrusive characteristics about them.

There may be some privacy-intrusive aspects to the tort of passingoff. In that tort goods are represented to be those of the plaintiff when they are in fact those of the defendant. Some of the ways of committing this tort may include appropriation of the plaintiff's name, imitation of his goods or use of a picture of him. ${ }^{49}$ In Krouse v. Chrysler Canada Ltd. ${ }^{\mathbf{0}}$ Haines J. stated:

\footnotetext{
The passing-off strand is more clearly on point. What could be a more precise example of 'an improper appropriation of the plaintiff's reputation' than appropriating that reputation in the commercial exploitation of one's goods. If it is accepted that there is a general business of giving endorsements and being involved in advertising promotion, and that at the very least professional athletes are part of that business, and that on the evidence adduced at trial Krouse is involved in that business, then the common ground necessary for passing-off actions is established. In this context I do not see any difference between A passing-off B's endorse-

4 Proof of either serves to defeat the defence of qualified privilege. See Adam v. Ward [1917] A.C. 309.

4. See Sharp, supra, n. 4 at 102 et seq.

46 See Hedley Byrne v. Heller [1964] A.C. 465; Central B.C. Planers v. Hocker (1970) 10 D.L.R. (3d) 689; and Dodds v. Millman (1964) 45 D.L.R. (2d) 472.

17 See Derry v. Peek (1889) 14 App. Cas. 337.

4* There is a privacy-intrusive aspect about any civil or criminal wrong which causes nervous shock or emotional distress. It is for precisely this reason that the courts have recognized it only in recent years. See Cook v. Swinfen [1967] 1 W.L.R. 457. Roman law and civil law jurisdictions appear to have recognized it earlier and more readily. See Institutes of Justinian, 4.4.1 and Robbins v. CBC (1957) 12 D.L.R. (2d) 35.

${ }^{19}$ Krouse v. Chrysler Canada Ltd. (1970) 12 D.L.R. (3d) 463, (1972) 2 O.R. 133; and Henderson v. Radio Corporation Pty. Ltd. [1960] (S.R.) N.S.W. 576.

so Supra, n. 49 at 152 (O.R.).
} 
ment as being C's and A either fabricating C's endorsement or using C's picture without permission. In either situation $\mathrm{C}$ suffers the very injury which passing-off is intended to remedy.

In this manner Haines J. was able to award damages to a football player whose photograph had been used without his permission in material advertising the defendant's product. This tort, in this instance, covers some of the same ground as defamation. ${ }^{51}$ Here the award of damages depended on the falsity of the impression created in the mind of the viewer of the picture. Substantial truth of the statement or impression will preclude recovery in this tort.

Adaptation of, and in some cases, resurrection of old or outmoded torts have been suggested as partial panaceas for invasions of privacy. In the aggregate, these torts, together with the more modern ones of defamation, deceit, negligent misrepresentation and passing-off may form a fairly comprehensive body of tort law for the redress of invasions of privacy.

In one such action, that for breach of confidence, the court may not only grant an injunction, but may also award damages. ${ }^{52}$ The injunctive relief is necessitated by the prospect of publication. This form of relief is aimed at restraining undue publicity rather than at improper collection of information.

Newark has suggested that a revival of the tort of besetting might well curtail some of the intrusions which do not amount to paratrespassory invasions: ${ }^{33}$

There is also a strong case for the resuscitation of the tort of besetting, which goes back to the days of Fitzherbert: it would be a very effective weapon against the news-vultures who descend on any family home which has suffered some great calamity.

Although the tort appears to have been in desuetude for some time, the gist of it is the unreasonable watching or besetting of the dwelling house or place of business of another. It, too, would be of relatively limited use (even together with the extension of the tort of trespass suggested by Newark) because the tort of watching and besetting appears to be concerned with the activities of the defendent at the time of gathering the information and not with the possibility of undue or unreasonable publicity afterwards. Nevertheless, it may in this sense serve as a complement to the restraint of breach of confidence.

The tort of invasion of privacy has become well established in U.S.

s1 See Tolley v. Fry [1931] A.C. 333. The only major difference between this case and Krouse v. Chrysler Canada Ltd., supra, n. 49, was that in the latter case defamation was not pleaded.

s2 Argyll v. Argyll [1965] 1 All E.R. 611; and Prince Albert v. Strange (1849) I Mac. \& G. 25, 41 E.R. 1171.

33 Newark, Book Review, (1971) 87 L.Q.R. 264.

st See, e.g., Melvin v. Reid (1931) 112 Cal. App. 285. The states of Nebraska, Rhode Island, Texas and Wisconsin have not yet afforded protection against invasions or privacy per se. There have been several judicial pronouncements to the effect that the tort of invasion of privacy is not capable of being developed at common law in the absence of precedent. See Brunson v. Ranks Army Stores (1955) 161 Neb. 519,73 N.W. (2d) 803; and Yoeckel v. Samonig (1956) 75 N.W. (2d) 925. However, there have been many judicial decisions in the U.S.A. recognizing the tort since the turn of the century when the Court of Appeals of New York decided Roberson v. Rochester Folding Box Co. (1902) 171 N.Y. 538, 64 N.E. 442. In that case the defendant used a picture of the plaintiff without her consent to advertize its flour. The Court of Appeals decided that the common law offered no redress for this conduct. There followed a public outcry and the introduction and passage of a bill in the New York legislature making such conduct both tortious and a misdemeanour. Only two states have this statute and in the remaining states the courts have recognized that the right exists at common law. Clearly articles such as those written by Warren $\&$ Brandeis, Prosser and Winfield have had a marked effect. See Prosser, Privacy, (1960) $48 \mathrm{Calif}$. L. Rev. 383; Bloustein, Privacy As An Aspect of Human Dignity: An Answer to Dean Prosser, (1964) 39 N.Y.U. L. Rev. 962. Beaney, The Right to Privacy and American Law, (1966) Law and Contemp. Prob. 253; Davis, What Do We Mean by Right to Privacy?, (1959) 4 S.D. L. Rev. 1; Ezer, Intrusion on Solitude, (1961) 21 Law in 
jurisdictions in recent years..$^{54}$ The coining of the expression "right to privacy" is popularly attributed to an article written by Godkin and closely followed by that of Warren and Brandeis. ${ }^{55}$ The tort is now gen. erally taken to have the form ascribed to it by Prosser ${ }^{56}$ and protects against the following invasions:

(1) appropriation for the defendant's benefit of the plaintiff's name or likeness;

(2) intrusion upon the plaintiff's physical solitude or seclusion;

(3) publicity of an objectionable kind being given to private information about the plaintiff, and

(4) publicity placing the plaintiff in a false light in the public eye.

It is quite unclear whether there exists at common law a tort of invasion of privacy in Canadian jurisdictions. ${ }^{57}$ Judges appear to have studiously avoided the issue. Haines J. stated in Krouse v. Chrysler Canada Ltd. that: ${ }^{58}$

... I specifically decline to rule on the issue of whether there is a common law right to privacy in Ontario.

It may be surmised that a greater acceptance of this tort will be recognized in England and Canada. ${ }^{99}$ If it is received in the form outlined by Prosser it may become a valuable addition to protection against infringements on privacy. The first and fourth categories set out by Prosser may already be protected by the torts of passing-off and defamation and the third may to some extent be protected by injunction on the basis of breach of confidence but intrusions short of trespass will go unredressed without the recognition of this tort.

This accretion of tort remedies is still subject to two major deficiencies. One is that the plaintiff may never know that his privacy has been intruded upon. The other is that all these private law remedies are costly, slow and only serve to redress damage already done. (It is recognized that tort, contract and copyright actions will have a

Transition 63; Farquhar, The Statutory Right of Privacy in the State of New York and Its Importance for New Zealand, (1970) 5 N.Z.L. Rev. 277; Feinberg, Recent Developments in the Law of Privacy, (1948) Colum. L. Rev. 713; Gordon, Right of Property in Name, Likeness, Personality and History, (1961) 55 N.W.U. L. Rev. 553; Green, Right to Privacy, (1932) 27 Ill. L. Rev. 237; Gutteridge, The Comparative Law of the Right of Privacy, (1931) 47 L.Q.R. 203; Kacedan, The Right of Privacy, (1932) 12 Bost. U.L.R. 353, 600; Kalven, Privacy in Tort Law-Were Warren and Brandeis Wrong?, (1966) 31 Law and Contemp. Prob. 326; Larremore, The Law of Privacy, (1941) 39 Mich. L. Rev. 526; Miller, Personal Privacy in the Computer Age, (1969) 67 -Mich. L. Rev. 1091; Nizer, Right of Privacy, (1941) 39 Mich. L. Rev. 526; Paton, Broadcasting and Privacy, (1938) 16 Can. Bar Rev. 425; Pedrick, Publicity and Privacy: Is It Any of Our Business?, (1970) 20 U.T.L.J. 391; Raglund, The Right of Privacy, (1929) 17 Ky. L.J. 85; Taylor, Privacy and the Public, (1971) 34 Mod. L. Rev. 288; Yang. Privacy: A Comparative Study of English and American Law, (1966) 15 Int. \& Comp. L.Q. 175; Wade, Defamation and the Right of Privacy, (1962) 15 Vand. L. Rev. 1093; Wagner, The Development of the Theory of the Right to Privacy in France, (1971) Wash. Univ. L.Q. 45; Walton, The Comparative Law of the Right to Privacy, (1931) 47 L.Q.R. 219; Warren \& Brandeis, The Right to Privacy, (1890) 4 Harv. L. Rev. 193; Westin, Science, Privacy and Freedom: Issucs and Proposals for the 1970's, (1966) 66 Colum. L. Rev. 1003, 1205; Winfield, Privacy, (1931) 47 L.Q.R. 23; Yankwich, The Right of Privacy, (1952) 27 Notre Dame Law 499.

ss Godkin, Scribner's Magazine. July, 1890, at 65 and Warren and Brandeis, The Right to Privacy, (1890) 4 Harv. L. Rev. 193.

ss Privacy, (1960) 48 Calif. L. Rev, 383 and Torts 802 (4th ed. 1971). Prosser sets out many decisions supporting his fourfold classification.

57 Clearly there is statutory acceptance of such a tort in British Columbia, Manitoba and to some extent Quebec. See Privacy Act, S.B.C. 1968, c. 39, Privacy Act, R.S.M. 1970, c. P125, and arts. 1053 and 1054 Code Civile.

se Supra, n. 49 at 140 .

59 Privacy has generally not been recognized in English law: Winfield, The Right to Privacy, (1931) 47 L.Q.R 23; and Brittan, The Right of Privacy in England and the United States, (1962-3) 37 Tul. L. Rev. 235. But see Winfield and Jolowicz, Tort 50 (9th ed. 1971) where interferences are regarded as being either with privacy of property or personal privacy. This recognition under the title of "Doubtful Wrongs" may ultimately give rise to a less qualified recognition. 
prescriptive effect but it may prove possible to safeguard people's interests in their privacy in some way in addition to the traditional tort and other remedies.)

\section{STATUTORY PROTECTION}

Two jurisdictions in Canada, namely British Columbia and Manitoba, have statutes giving protection against invasions of privacy. The two statutes differ but both give a broad and general protection against such invasions. The first Canadian statute was the Privacy Act of British Columbia which provides in section 2 that: 60

2. (1) It is a tort, actionable without proof of damage, for a person, wilfully and without a claim of right, to violate the privacy of another.

(2) The nature and degree of privacy to which a person is entitled in any situation or in relation to any matter is that which is reasonable in the circumstances, due regard being given to the lawful interests of others; and in determining whether the act or conduct of a person constitutes a violation of the privacy of another, regard shall be given to the nature, incidence, and occasion of the act or conduct and to the relationship, whether domestic or other, between the parties.

(3) Privacy may be violated by eavesdropping or surveillance, whether or not accomplished by trespass; but nothing in this subsection shall be construed as restricting the generality of subsections (1) and (2).

Sections 2 and 3 of the Privacy Act ${ }^{61}$ of Manitoba contain substantially the same prohibition as the British Columbia Act although the Manitoba Act contains more illustrations and examples of invasions. However, it is important to notice that although the British Columbia Act restricts recovery to wilfully committed invasions ${ }^{62}$ the Manitoba Act has no such restriction and allows action against one who:63

... substantially, unreasonably, and without claim of right violates the privacy of another person...

These are the only two general statutory prohibitions in existence in Canadian jurisdictions. Both Acts supply some defences for the tort liability they create. Both Acts have the defences of consent; activities of a peace or public officer when they are proportionate to the subjectmatter of the investigation and not incidental to a trespass; exercise or protection of a lawful right of defence of person, property or other interest; authorization by a statute or by a court; or that a publication was in the public interest, was fair comment or was privileged according to the rules of defamation. ${ }^{64}$ Since Manitoba's Act extends the tort to cover even negligent invasions of privacy there is an additional defence: 65

that the defendant, having acted reasonably in that regard, neither knew or should reasonably have known that the act, conduct or publication constituting the violation would have violated the privacy of any person....

There are other statutes which attempt to guard against privacy-

$\infty 0$ S.B.C. 1968, c. 39.

o1 S.M. 1970, c. 74; R.S.M. 1970, c. P125.

62 Seaton J. in the trial court hearing Davis v. McArthur (1969) 10 D.L.R. (3d) 250 at 253 construed the term wilfully to mean... "intentionally, knowingly and purposely without justifiable excuse ... as distinct from a negligent act." This has the effect of requiring the plaintiff to prove either intention or its equivalent recklessness. The British Columbia Court of Appeal decision at (1971) 17 D.L.R. (3d) 760 does not appear to cast doubt on this proposition.

63 S.M. 1970, c. 74; R.S.M. 1970, c. P125.

of See the Privacy Act, R.S.M. 1970, c. P125, s. 5; and the Privacy Act, S.B.C. 1968, c. 39, s. 3.

os Privacy Act, R.S.M. 1970, c. P125, 8. 5(6). 
intrusive conduct falling within one of the broad categories of undue publicity, intrusion or improper control of information. ${ }^{66}$ However, no other statutes are so broad as to encompass, at least potentially, all these forms of privacy-intrusive conduct. This result is produced by very vague wording in these two Acts. ${ }^{67}$ However, the effect of the British Columbia Act is not as wide as may have been surmised because of the necessity of wilfulness, intention or recklessness. ${ }^{68}$ The common law tort of invasion of privacy, if it can be said to exist in any Canadian jurisdiction, would be accommodated within the framework of the Manitoba Act. ${ }^{69}$

\section{OTHER LEGAL PROTECTION}

There are various other forms of legal protection the most important object of which is not the protection of privacy. Naturally, it is a matter of judgment as to precisely what the purposes of these various forms of legal protection are. They may have their origin in a statute, in the common law or in custom. An example of a statute which has the peripheral effect of protecting privacy may be the British Columbia Landlord and Tenant Act, ${ }^{70}$ which in section 46 requires that notice be given by a landlord entering premises occupied by his tenant and that entry should only take place between certain times of the day,

... except (a) in cases of emergency; or (b) with the consent of the tenant given at the time of entry....

\section{In Re MacIsaac and Beretanos ${ }^{71}$ Levey Prov. Ct. J. stated: ${ }^{72}$}

In my view, s. 46 of Part II of the Landlord and Tenant Act, creates a statutory right to privacy. The right to privacy was considered by two eminent legal minds, S.D. Warren and Louis Brandeis, in an article entitled "The Right to Privacy" in 4 Harv. L. Rev. 193 (1890). This article, perhaps treatise, on the right to privacy in the United States, dealt with an analysis of that right in common law, and at p. 21 the authors suggested:

"The right of property in its widest sense, including all possession, including all rights and privileges, and hence embracing the right to an inviolate personality, affords alone that broad basis upon which the protection which the individual demands can be rested.'

In legislating s. 46, the provincial Legislature must have considered the common law right to privacy, and the need to incorporate that right in a statute, thereby creating a statutory tort. That this is so, is evidenced by the fact that there has

So See the classification attempted above.

67 Both Acts state: "It is a tort . . to violate the privacy of another." See Privacy Act, S.B.C. 1968, c. 39, S. 2(1); and Privacy Act, R.S.M. 1970, c. P125, s. 2 (". . . A person who . . . violates the privacy of another person ... commits a tort...").

6s See Davis v. McArthur (1971) 17 D.L.R. (3d) 760.

${ }^{69}$ Infra, n. 72. For the tort of privacy as it has been developed in U.S. jurisdictions see Prosser, Torts 802 et seq. (4th ed. 1971). See also Cornfield, The Right to Privacy in Canada, (1967) 25 Fac. L. Rev. 103; Green, The Duty to Give Accurate Information, (1965) 12 U.C.L.A. L. Rev. 464; Switkay, Tort Liability of Credit Investigating Agencies, (1957) 31 Temp. L.Q. 50; and Wade, Defamation and the Right of Privacy, (1961-2) 15 Vand. L. Rev. 1093

70 R.S.B.C. 1960, c. 207. This provision, apparently, created a right to privacy incidental to the main purpose of the Act which was to harmonize relations between landlord and tenant.

7 (1972) 25 D.L.R. (3d) 610.

${ }^{72}$ Id. at 614 and 615. Although Levey Prov. Ct. J. speaks of a "common law right to privacy" his decision is founded on the basis of a statutory tort. Thus, his comments relating to a "common law right to privacy" are merely obiter dicta but they, nevertheless, tend to colour the specific abstention of Haines J. in Krouse v. Chrysler Canada Ltd. (1972) 2 O.R. 133 from deciding whether there exists a common law right to privacy in Ontario. Furthermore, the comment of Levey Prov. $\mathrm{Ct}$. J. indicates that the Privacy Act S.B.C. 1968, c. 39, does not set out all the law generally relating to privacy. By acknowledging a "common law right to privacy" he inferentially refutes the argument that the Privacy Act codifies the law and asserts that there is a vestigial common law right. It is not intended to read too much into the words of Levey Prov. Ct. J. but there is a paucity of more direct authority. See also Re K. C. Irving v. The Queen (1971) 4 C.P.R. (2d) 120. 
been provided no remedy, either by way of a penalty pursuant to 8.62 of the Landlord and Tenant Act, Part II, or by way of summary application to the Small Claims Court for a violation of 8.46 ....

... Accordingly, for the foregoing reasons, I hold that it was intended by the Legislature that 8 . 46 created the right to privacy, the breach of which constitutes a tort giving rise to damages.

Various other aspects of the problem caused by privacy-intrusive conduct are covered by particular and narrow statutes. ${ }^{73}$ Some statutes require both the keeping of records by government departments and their being kept secret. An example is the records kept under the aegis of the Statistics Act. ${ }^{74}$ There is also a provision for sanctions to be applied to the unauthorized gathering of identifiable information from income tax returns and other incidental information. ${ }^{75}$ The Personal Investigations Act ${ }^{76}$ of Manitoba is a fairly recent effort to restrict the information retained on an individual as the result of a personal investigation.

The U.S. Fair Credit Reporting Act ${ }^{77}$ did start a trend by limiting the type of information that may be collected and specifying to whom it may be released and on what conditions. One of the important measures taken by this Act is to require the consent of the subject of the information. The Manitoba Personal Investigations Act ${ }^{78}$ similarly limits the collection, retention and dissemination of information. As such it attempts to remove some of the worst abuses in the realm of excessive publicity and misuse of information. Some of the provisions of the Act ban the gathering and retention of various types of information: ${ }^{79}$

No personal report shall contain

(a) any reference to race, religion, ethnic origin, or political affiliation of the subject unless this information is voluntarily supplied by the subject; or

(b) information regarding any bankruptcy of the subject which occurred fourteen years or more prior to the making of the report; or

(c) information regarding any writs, judgments, collections or debts that are statute barred; or

(d) information regarding writs issued against the subject more than twelve months prior to the making of the report if the present status of the action is not ascertained; or

(e) information as to any judgment against the subject unless mention is made of the name and address of the judgment creditor as given at the date of entry of the judgment and the amount of the judgment; or

(f) any other adverse factual or investigative information that is more than seven years old unless it is voluntarily supplied by the subject or is otherwise permitted by this Act; or

(g) any investigative information regarding the subject unless reasonable efforts have been made to corroborate the information.

In addition to the fact that these items of information shall not be listed in a personal report other sections of the Act specify that the written consent of the subject must be obtained before an investigative report may be conducted on him; 80 that the contents of any report

73 Recognition of tort liability flowing from a statute providing an essentially criminal penalty or no penalty at all is a development not unlike that in Bivens v. Six Unknown Named Agents (1971) 91 S. Ct. 1999.

74 See ss. 10 and 15 of the Statistics Act, R.S.C. 1970, c. S.16.

7s See 8. 196(1)(a) and (6), Income Tax Act, R.S.C. 1970, c. 1-5.

76 S.M. 1971, c. 23-c. P33. The Act contains important provisions other than the one mentioned here.

77 Pub. L. $91-508$ (1970); U.S.C.A. 15, s. 1681

78 Supra, n. 76.

79 Id. 8. 4.

so Id. s. 3. This requirement of written consent applies both to the so-called file reports and to investigative reports. 
shall not be divulged except to the user or his agent, the assignee of an agreement for credit, insurance or tenancy, a government agency or police officer and the subject of the report:81 and that the subject is to be informed of any denial of a benefit where a personal investigation has been conducted. ${ }^{82}$ The subject of the report also has a right to see what reports are being retained on him and he has a right to protest information retained on him, which information must then be verified. Where information cannot be verfied it must be expunged. If information is retained on file the subject has a right to record a protest. ${ }^{83}$

Acts like the Personal Investigations Act ${ }^{84}$ of Manitoba are to be encouraged because they do fill a large gap in the protection of privacy. The same result could probably never have been achieved by a voluntary and concerted action on the part of citizens. Furthermore, it recognizes the interest of the subject of the report in the information circulating about him. This type of Act is an important step forward but it does not preclude the intrusive behaviour which is almost, but not quite, trespassory in nature. For this no redress exists unless it. be under either the Privacy Act or a common law tort of privacy.

\section{CONCLUSION}

The types of protection outlined under $V$, are obviously sporadic and limited. It is intended to give only a sample of additional legal protection of privacy interests. Since a generalized and coherent protection of the whole sphere of individual privacy has not been attempted in any common law jurisdiction, such instances of protection of privacy interests that exist do so with greater or less particularity. Perhaps one of the most general is the statutory or common law protection of privacy by a tort remedy. However, even this approach leaves out of account the possible contributions which might be made by regulations, administrative agencies and other devices..$^{85}$

The development of a rational theory of privacy will be beneficial but it is recognized that most forms of protection do emanate as direct responses to apprehended abuses. This fact tends to produce a rather fragmented sphere of privacy.

81 Id. 8. 5 .

82 Within ten days from the date of denial. Id. 8 . 6. In accordance with 8.7 he is also to be informed of the source of any report and upon what it was based.

83 Id. 88. 7.14. These provisions parallel those of the U.S. Fair Credit Reporting Act, supra, n. 77, but appear to be an improvement upon that Act in that a heavier onus is placed upon the reporting agency. Furthermore, the practical problem of the user of the report not stating its existence and identifying the report is not present in the Manitoba Act because the user is bound to mention the existence of the report anytime there is a refusal of a benefit and a personal investigation has been conducted.

s4 Supra, n. 76.

ns The Canadian Government through the Departments of Communications and Justice established a Task Force to examine all possible aspects of the problem of adequate protection of privacy. This was given added impetus by the advent of computers in many stages of the information handling process. The Report entitled Privacy and Computers (1972), pointed out some widespread apprehensions. It was not as extensive as the Younger Committee Report on Privacy (1972) presented to the Parliament of Great Britain. 